\title{
Eksplorasi Teori Gratifikasi untuk Layanan Jejaring Sosial: Studi Kasus Sikap Pengguna terhadap Instagram di Indonesia
}

\author{
T L M Suryanto*1, H A Puteri ${ }^{2}$, A Pratama ${ }^{3}$ \\ 1,2,3 Program Studi Sistem Informasi, Fakultas Ilmu Komputer Universitas Pembangunan \\ Nasional "Veteran" Jawa Timur
}

E-mail: trilathif.si@upnjatim.ac.id ${ }^{* 1}$, hidayatulainip@gmail.com², aristapratama.si@upnjatim.ac.id ${ }^{3}$

Masuk: 11 Januari 2019, direvisi: 18 Februari 2019, diterima: 24 Februari 2019

\begin{abstract}
Abstrak. Instagram merupakan Social Network Service (SNS) yang populer di kalangan pengguna smartphone. Fakta ini didukung oleh hasil survei dalam laporan yang berjudul "Digital In 2018 In Southeast Asia" yang dihimpun oleh We Are Social, perusahaan media asal Inggris yang bekerja sama dengan Hootsuite. Hasil survei tersebut menyebutkan bahwa Instagram menempati peringkat ketiga aplikasi yang paling banyak diunduh pada tahun 2018. Menyoroti respon pengguna smartphone yang begitu besar terhadap Instagram, maka dalam penelitian ini dilakukan eksplorasi faktor penerimaan sikap pengguna terhadap Instagram di Indonesia dengan menggunakan Teori Uses And Gratification (UGT). Pemenuhan penerimaan Instagram dibagi menjadi Cognitive, Hedonic, Integrative, dan Social Integrative. Dalam penelitian ini dikumpulkan tanggapan dari 400 pengguna Instagram di Indonesia. Data yang diperoleh diolah dan dianalisis dengan menggunakan Metode Structural Equation Modelling (SEM) dan perangkat lunak WarpPLS 6.0. Dari penelitian ini diperoleh dua temuan. Pertama, sikap pemuasan pengguna terhadap Instagram dipengaruhi oleh Cognitive, Hedonic, dan Social Interactive. Kedua, Sosial Interactive Gratification merupakan faktor yang dapat meningkatkan Cognitive Gratification, Hedonic Gratification, dan Integrative Gratification.
\end{abstract}

Kata kunci: Social Network Service (SNS); Instagram; Uses and Gratification Theory (UGT)

Abstract. Instagram is a Social Networking Service (SNS) that is popular among smartphone users. This fact is supported by the results of a survey in report entitled "Digital in 2018 in Southeast Asia" which was compiled by We Are Social, a British media company that collaborated with Hootsuite. The survey results contain data on Instagram on 2018. Highlighting smartphone users 'response to Instagram is very large. Therefore in this study, the factors that influence users' ratings of Instagram in Indonesia by using the Theory of Use and Gratification (UGT) were conducted. Fulfillment of Instagram receipts have been divided into Cognitive, Hedonic, Integrative, and Social Integrative. In this study, responses were gathered from 400 Instagram users in Indonesia. The data obtained was processed and analyzed using the Structural Equation Modeling (SEM) Method and WarpPLS 6.0 software. From this study two findings were obtained.

Suryanto, Puteri, Pratama (Eksplorasi Teori Gratifikasi untuk Layanan Jejaring Sosial: Studi Kasus Sikap Pengguna terhadap Instagram di Indonesia) 
First, user satisfaction towards Instagram is influenced by cognitive, hedonic, and social integrative. Second, social interactive gratification is a factor that can increase cognitive gratification, hedonic gratification, and integrative gratification.

Keywords: Social Network Service (SNS); Instagram; Uses and Gratification Theory (UGT)

\section{Pendahuluan}

Pada era digital ini, orang-orang cenderung untuk berkenalan satu sama lain dengan bertukar alamat akun dan membuat pertemanan di media sosial. Berbeda dengan jaman dulu, perkenalan dilakukan dengan cara konvensional yakni dengan bertukar kartu nama [1]. Hal ini dikarenakan hampir setiap orang memiliki telepon pintar dan memiliki akun media sosial, seperti Facebook, Twitter, Path, Instagram, dan sebagainya. Kondisi ini menjadi sebuah kelaziman yang mengubah bagaimana cara berkomunikasi pada era serba digital ini.

Social Network Service (SNS) merupakan layanan online yang bertujuan untuk membangun hubungan sosial di antara orang-orang untuk berbagi minat dan kegiatan [2]. Di Indonesia, berdasarkan hasil survey yang dilakukan oleh We Are Social diketahui bahwa Instagram adalah media sosial yang paling banyak digunakan dan berada di peringkat ketiga pada kategori social network. Selain itu, diketahui bahwa ada 53 juta pengguna aktif Instagram tiap bulannya. Besarnya minat pada Instagram ini dikarenakan fiturfiturnya yang menarik, antara lain pengguna dapat mengedit (melalui filter pradesain), menambahkan caption (tulisan di bawah gambar), menggunakan emoticons, membingkai unggahan di storyline, menggunakan tanda '\#' untuk menghubungkan konten yang sama, serta membagikan unggahan platform sosial media lain [3][4].

Karena tingginya minat pengguna pada Instagram, maka pada penelitian ini dilakukan eksplorasi faktor penerimaan sikap pengguna terhadap Instagram di Indonesia dengan menggunakan Teori Uses And Gratification (UGT). UGT adalah pendekatan untuk memahami mengapa dan bagaimana orang secara aktif mencari media khusus untuk memenuhi kebutuhan yang spesifik [5]. UGT adalah teori yang cocok untuk penelitian ini karena dengan UGT mengasumsikan pengguna mempunyai pilihan alternatif untuk memenuhi kebutuhan [6]. Asumsi Teori UGT, yaitu: (1) pengguna berinisiatif dalam menghubungkan kepuasan kebutuhan pada pilihan media tertentu dan pilihan terdapat pada pengguna, (2) pengguna memilih media berdasarkan tujuan, (3) pengguna yang sadar motivasi mereka untuk memilih media tertentu, (4) penilaian mengenai nilai isi media hanya dapat dinilai oleh pengguna, dan (5) media saling berkompetisi untuk kepuasan pengguna [7].

Instagram diluncurkan pada tahun 2010, dan sejak diluncurkan belum ada analisis Instagram yang menggunakan UGT dengan mediasi komputer yang mencangkup penggunaan Instagram di seluruh Indonesia. Analisis yang pernah dilakukan sebelumnya tidak mencakup pada pengguna di Indonesia. Penelitian ini diharapkan dapat menjelaskan kepuasan yang diberikan Instagram terhadap penggunanya di Indonesia.

\section{Kerangka Teoritis}

Bagian ini menjelaskan kerangka teori yang digunakan dan menjadi landasan metodologi penelitian. Kerangka teori penelitian ini meliputi SNS, Uses and Gratification Theory (UGT), dan attitude towards SNS.

\subsection{SNS}

Berdasarkan teori social networking tradisional, social networking terjadi ketika jaringan komputer dapat menghubungkan orang atau organisasi dengan hubungan sosialnya seperti persahabatan, teman kerja, dan lain-lain [8]. Berbeda dengan social networking modern, social networking modern terjadi ketika 
relasi pertemanan dilakukan melalui media digital yaitu menggunakan internet yang dioperasikan melalui situs-situs jejaring sosial atau Social Networking Sites [9].

Social Network Service (SNS) merupakan layanan online yang bertujuan untuk membangun hubungan sosial di antara orang-orang yang berbagi minat [2]. SNS dapat berupa situs web di mana penggunanya dapat membuat profil pribadi (personal profile), berkomunikasi, dan berinteraksi sosial dengan sesama teman dengan mengunggah, menyukai, dan berkomentar di konten seperti photo, kata-kata, dan video yang dibagikan di feeds [10]. SNS telah menjadi bagian dari komunikasi sehari-hari dan semakin banyak individu yang bergantung pada SNS untuk tetap berhubungan dengan orang lain [11][12]. Situs web SNS yang populer antara lain Facebook, Twitter, dan Instagram [13].

\subsection{Uses and Gratification Theory (UGT)}

Uses and Gratification Theory atau UGT mcrupakan salah satu teori yang paling terkenal pada bidang komunikasi. UGT untuk pertama kalinya diperkenalkan oleh Herbert Blumcr dan Elihu Katz pada tahun 1974 yang menyebutkan bahwa penelitian diarahkan untuk mencari jawaban terhadap pernyataan atas hal apa saja yang dilakukan media pada khalayak [14].

UGT menunjukkan bahwa permasalahan utamanya bukan pada bagaimana cara media mengubah sikap dan perilaku khalayak, tetapi lebih kepada bagaimana media memenuhi kebutuhan pribadi dan sosial khalayak, sehingga sasarannya pada khalayak yang aktif, yang memang menggunakan media untuk tujuan khusus [6][14]. Dengan menggunakan UGT bisa dipahami interaksi orang dengan media melalui pemanfaatan media oleh seseorang (uses) dan kepuasan yang diperoleh (gratification) [6].

Menurut UGT, konsumen media mempunyai kebebasan untuk memutuskan bagaimana mereka menggunakan media, lewat media mana, dan bagaimana media itu berdampak pada dirinya [6][14]. Audiens/pengguna punya alternatif lain untuk memenuhi kebutuhan dan bisa saja menolak informasi yang diberikan oleh media [6][14]. Kepuasan yang diperoleh (gratification) dari media meliputi Cognitive Gratification, Hedonic Gratification, Integrative Gratification, dan Social Interactive Gratifications [15], [16].

Ha dkk. menerapkan UGT yang diperlihatkan pada gambar 1 sebagai metode uji Facebook dan KakaoTalk di Korea [16]. Social Interactive Gratification atau gratifikasi interaksi sosial memberikan pengaruh yang signifikan terhadap semua variabel gratifikasi lainnya sedangkan Mobile Convenience memiliki dampak yang signifikan pada semua kepuasan lainnya.

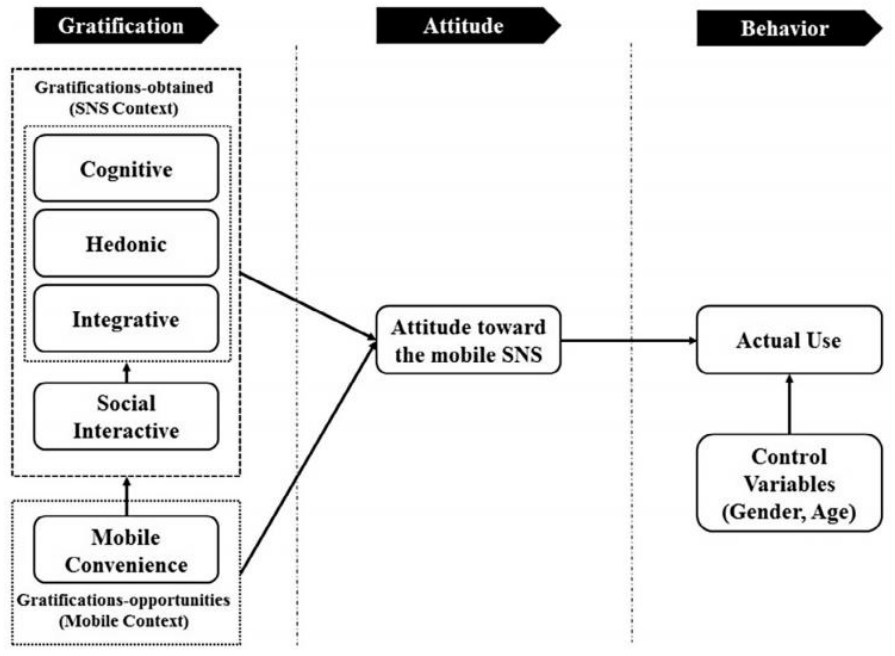

Gambar 1. Model UGT [16] 


\section{Metodologi}

Berdasarkan faktor kepuasan dalam UGT, model penelitian ini dibuat untuk menemukan faktor kepuasan yang didapat dari penggunaan Instagram di Indonesia serta hubungan antara kepuasan tersebut. Variabel dependen dalam model ini adalah kognitif (cognitive), hedonik (hedonic), integratif (integrative), dan interaksi sosial (social interactive), sedangkan variabel dependen dalam penelitian ini adalah attitude towards SNS atau sikap pengguna terhadap SNS. Untuk menyesuaikan ruang lingkup penelitian maka peneliti melakukan modifikasi dari model penelitian sebelumnya. Gambar 2 menunjukkan model konseptual penelitian ini.

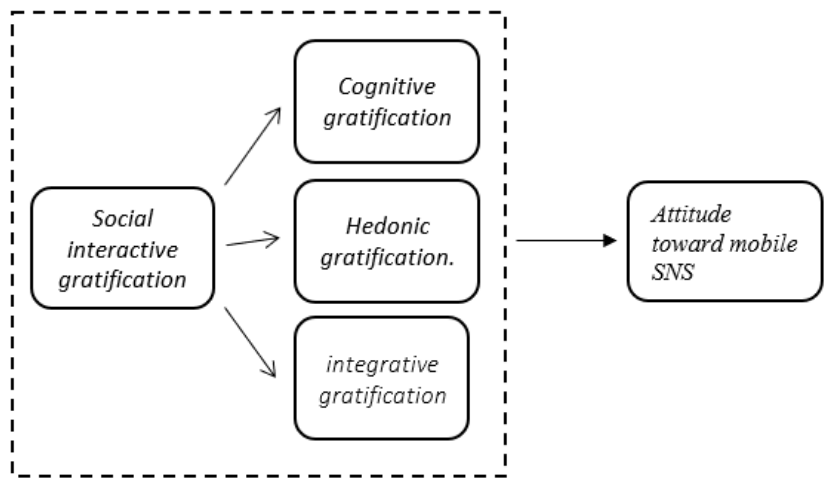

Gambar 2. Model Konseptual

\subsection{Data Penelitian}

Data penelitian ini diperoleh dari kuesioner yang disebarkan kepada responden. Responden yang digunakan dalam penelitian ini adalah pengguna Instagram di Indonesia. Data diperoleh dari enam wilayah Indonesia yang dibagi berdasarkan data Asosiasi Penyelenggara Jasa Internet Indonesia (APJII) 2017 yaitu Jawa, Bali-Nusa, Kalimantan, Sulawesi, Sumatera, dan Maluku-Papua [17]. Data diperoleh dari 5 sampai 25 Oktober 2018 secara online. Dari proses pengumpulan data diperoleh 400 data dengan persentase $57 \%$ responden laki-laki dan $43 \%$ perempuan dengan $18 \%$ responden berusia 13-18 tahun dan 82\% berusia 19-34 tahun. Penilaian pertanyaan kuesioner ini menggunakan skala 1 (sangat tidak setuju) sampai 5 (sangat setuju). Terdapat lima variabel yang digunakan dalam penelitian ini, yaitu: Cognitive Gratification, Hedonic Gratification, Integrative Gratification, Social Interactive Gratification, dan Attitude towards SNS.

3.1.1. Cognitive Gratification. Cognitive Gratification bisa disebut sebagai kepuasan keingintahuan (gratification of curiosity). Kebutuhan untuk memperoleh kepuasan keingintahuan ini didasarkan pada hasrat untuk memahami dan menguasai lingkungan, juga memuaskan rasa penasaran dan dorongan untuk menyelidiki [6][14]. Dalam penelitian ini, Cognitive Gratification dari Instagram yaitu kepuasan mendapatkan informasi dengan melihat postingan pengguna lain.

Pada aplikasi SNS lain seperti Snapchat, informasi dalam Cognitive Gratification mendukung pengaruh penggunaan dan pemenuhan kepuasan [18]. Pada penggunaan sosial media, Cognitive Gratification merupakan motivasi pengguna untuk menggunakan aplikasi tersebut [19][20]. Hal ini dikarenakan pengguna dapat memperoleh informasi tentang produk dan layanan yang diinginkannya, dengan memanfaatkan fungsi "following" [16]. Dari beberapa hasil penelitian di atas, dapat disimpulkan hipotesis sebagai berikut:

H1: Cognitive Gratification berdampak positif terhadap Attitude towards SNS. 
3.1.2. Hedonic Gratification. Hedonic Gratification terkait dengan kegiatan beristirahat, bersantai, menghabiskan waktu, dan memperoleh kepuasan atas pengalaman yang menyenangkan (gratification of a strengthening joyful experience) [15]. Pengguna mementingkan hiburan dalam pemenuhan kepuasan terhadap SNS [21]. Dalam penelitian ini Hedonic Gratification dari Instagram yaitu kepuasan untuk menghabiskan waktu dan mendapatkan kesenangan dengan menggunakan Instagram.

Hedonic Gratification adalah alasan utama penentuan pengguna terhadap sikapnya terhadap mobile SNS [16]. Layanan seperti game, musik, dan berbagi foto di mobile SNS membawa banyak kesenangan kepada pengguna [22]. Pada aplikasi Snapchat, penggguna mendapatkan kepuasan dalam menghabiskan waktu dan relaksasi [18]. Sedangkan pada Facebook, kepuasan dalam memperoleh hiburan dan melepaskan diri dari rutinitas adalah yang paling banyak didapatkan oleh pengguna [23]. Dari beberapa hasil penelitian tersebut, dapat disimpulkan hipotesis sebagai berikut:

H2: Hedonic Gratification berdampak positif terhadap Attitude towards SNS.

3.1.3. Integrative Gratification. Integrative Gratification merujuk kepada kepuasan dalam membentuk identitas, meningkatkan nilai-nilai individu, dan membentuk rasa kedekatan atau kepemilikan dengan pengguna yang menggunakan media [6][15]. Hal itu bisa diperoleh dari hasrat akan harga diri [6][14]. Penggunaan SNS secara pasif juga termasuk Integrative Gratification [12]. Saat berpartisipasi dalam SNS (misalnya pengungkapan diri, berbagi, atau membuat komentar), beberapa pengguna harus mempertimbangkan apakah yang mereka posting sesuai untuk teman SNS mereka dan apakah emosi yang dinyatakan dalam pembaruan status akan merusak kesan mereka terutama saat menghadapi hubungan jarak jauh [24]. Dalam penelitian ini, Integrative Gratification dari Instagram adalah kepuasan dalam membuat identitas dan membangun kedekatan dengan pengguna lain menggunakan aplikasi Instagram.

Integrative pada SNS dapat dianggap sebagai faktor yang membedakan SNS dari media lain [16]. Integrative yang mempengaruhi keadaan psikologis individu [25]. Hal ini dikarenakan integrative meningkatkan kedekatan [26]. Mudah untuk membentuk nilai pribadi dengan membantu orang lain ketika menggunakan mobile SNS [16]. Dari beberapa hasil penelitian tersebut, dapat disimpulkan hipotesis sebagai berikut:

H3: Integrative gratification berdampak positif terhadap Attitude towards SNS.

3.1.4. Social Interactive Gratifications. Social Interactive Gratifications berkaitan dengan pemenuhan kontak dengan keluarga, teman, dan dunia. Hal tersebut didasarkan pada hasrat untuk berafiliasi [6][14]. Kebutuhan akan menjalin hubungan sosial di internet merupakan alasan utama yang dilakukan oleh khalayak dalam mengakses media [1]. Kepuasan interaksi sosial dan pertemanan melalui penggunaan sebuah aplikasi media sosial cukup jelas terlihat [2]. Hal paling jelas yang membedakan antara penggunaan SNS aktif dan pasif adalah ada tidaknya pemanfaatan SNS untuk berhubungan dengan pengguna lain [12]. Sebagai contoh, beberapa orang menggunakan SNS terutama untuk berinteraksi dengan orang lain, sedangkan ada yang menggunakan SNS hanya untuk mengamati apa yang terjadi dalam kehidupan orang lain [12]. Dalam penelitian ini Social Interactive Gratifications dari Instagram adalah kepuasan untuk dapat berinteraksi melalui kolom komentar dan Direct Message (DM) dengan pengguna lain menggunakan aplikasi Instagram.

Dengan menyediakan media untuk berkomunikasi dengan pengguna lain, mobile SNS dapat mendorong pengguna untuk mengungkapkan pendapat mereka [16]. Brown pada [27] menemukan bahwa Informasi yang dikumpulkan melalui interaksi sosial dianggap sebagai lebih dapat diandalkan daripada informasi yang diberikan oleh produk dan layanan yang disediakan oleh perusahaan. Informasi yang diperoleh melalui interaksi social dalam mobile SNS cenderung sesuai karena informasi ini didapat dari kenalan pengguna atau hal-hal yang berkaitan dengan mereka [28]. Layanan aplikasi SNS memungkinkan peningkatan cognitive gratification karena memberikan informasi yang dipelajari melalui hubungan sosial [16].

Suryanto, Puteri, Pratama (Eksplorasi Teori Gratifikasi untuk Layanan Jejaring Sosial: Studi Kasus Sikap Pengguna terhadap Instagram di Indonesia) 
Dalam konteks Social Interactive Gratification, pengguna lebih cenderung membenamkan diri dalam interaksi dan memperoleh pengalaman yang menarik dengan bertukar cerita lucu dengan kenalan [16] [22]. Pengguna tidak hanya mendapatkan informasi selama berinteraksi dengan teman-teman dalam percakapan tetapi mereka juga merasa senang dalam proses ini [29]. Dengan ini Social Integrative Gratification memungkinkan adanya peningkatan Hedonic Gratification.

Social Interactive Gratification juga meningkatkan Integrative Gratification dengan kenalan atau mampu menemukan identitas dan meningkatkan kedekatan antar pengguna [16]. Pada saat melakukan interaksi sosial pengguna cenderung menjadi semakin dekat [26]. Dari beberapa hasil penelitian tersebut, dapat disimpulkan hipotesis sebagai berikut:

H4: Social Interactive Gratification berdampak positif terhadap Attitude towards SNS.

H5: Social Interactive Gratification berdampak positif terhadap Cognitive Gratification.

H6: Social Interactive Gratification berdampak positif terhadap Hedonic Gratification.

H7: Social Interactive Gratification berdampak positif terhadap Integrative Gratification.

3.1.5. Attitude towards SNS. Attitude towards SNS atau sikap terhadap SNS mengacu pada evaluasi keadaan psikologis yang mencakup atribut seperti baik-buruk, berbahaya-menguntungkan, dan menyenangkan-tidak menyenangkan [30][31]. Saat seseorang telah mengganggap apa yang dilakukannya baik maka orang tersebut akan terus melakukan penggunaan sesuatu [30].

\subsection{Pengukuran Data}

Semua variabel menggunakan pengukuran dengan skala likert dengan nilai dari 1 (sangat tidak setuju) sampai 5 (sangat setuju). Penelitian ini menggunakan SEM-PLS. SEM dipilih karena mempunyai dua kelebihan, yaitu mampu menguji model penelitian yang kompleks secara simultan (serempak), mampu menganalisis variabel yang tidak dapat diukur langsung (unobserved variables) dan memperhitungkan kesalahan pengukuran [32].

\subsection{Perhitungan Evaluasi Model Pengukuran}

Analisis outer model dilakukan untuk menilai reliabilitas dan validitas dari indikator-indikator pembentuk konstruk laten [33]. Evaluasi model pengukuran dilakukan dengan melihat reliabilitas, convergent validity, dan discriminant validity [34].

Pengujian reliabilitas instrumen penelitian atau kuesioner dirnaksudkan untuk mengetahui tingkat konsistensi alat ukur tersebut [35]. Reliabilitas instrumen menunjukkan pada suatu pengertian bahwa, suatu instrumen cukup dapat dipercaya untuk digunakan sebagai alat pengumpul data dan tidak bersifat tendensius atau mengarahkan responden untuk memilih jawaban-jawaban tertentu [35]. Convergent validity atau validitas konvergen berhubungan dengan prinsip bahwa pengukuran-pengukuran dari suatu konstruk seharusnya berkorelasi tinggi [33][36]. Sedangkan, discriminant validity atau validitas diskriminan berhubungan dengan prinsip bahwa pengukuran-pengukuran konstruk yang berbeda seharusnya tidak berkorelasi tinggi [36].

\subsection{Perhitungan Evaluasi Model Struktural}

Model struktural atau Inner model menunjukkan kekuatan estimasi antar variabel laten atau konstruk [33]. Pengujian model struktural dilakukan untuk memprediksi hubungan kausal (sebab-akibat) antar variabel atau pengujian hipotesis [36]. 


\section{Hasil dan Pembahasan}

Perangkat lunak analisis data yang digunakan adalah WarpPLS 6.0, berikut adalah hasil olah WarpPLS.

\subsection{Realibilitas dan Convergent Validity}

Reliabilitas dinilai dengan melihat Composite Reliability (CR), nilai CR harus lebih besar dari 0.70 agar bisa diterima [33]. Convergent validity untuk konstruk reflektif yaitu nilai loading harus di atas 0,70 dan nilai P signifikan $(<0,05)$ [37]. Jika indikator dengan loading di bawah 0,40 maka indikator tersebut harus dihapus [34]. Akan tetapi untuk indikator dengan loading antara 0,40 dan 0,70 indikator tersebut dapat dihapus jika meningkatkan nilai Average Variance Extracted (AVE) dan CR di atas batasannya [34]. Nilai batasan AVE adalah 0,50 dan CR sebesar 0,70 [34]. Reliabilitas dan Convergent validity dalam penelitian ini dapat dilihat pada tabel 1.

Tabel 1. Reliabilitas dan Convergent Validity

\begin{tabular}{|c|c|c|c|c|c|}
\hline \multirow{2}{*}{ Variabel } & \multirow{2}{*}{ Item } & \multicolumn{4}{|c|}{ Sampel } \\
\hline & & Loading & $P$ signifikan & $\mathbf{C R}$ & AVE \\
\hline \multirow{3}{*}{$\begin{array}{l}\text { Cognitive } \\
\text { Gratification }\end{array}$} & COG1 & 0.656 & $<0.001$ & \multirow{3}{*}{0.771} & \multirow{3}{*}{0.464} \\
\hline & COG2 & 0.798 & $<0.001$ & & \\
\hline & COG3 & 0.738 & $<0.001$ & & \\
\hline \multirow{3}{*}{$\begin{array}{l}\text { Hedonic } \\
\text { Gratification }\end{array}$} & HED2 & 0.518 & $<0.001$ & \multirow{3}{*}{0.714} & \multirow{3}{*}{0.444} \\
\hline & HED3 & 0.868 & $<0.001$ & & \\
\hline & HED4 & 0.862 & $<0.001$ & & \\
\hline \multirow{4}{*}{$\begin{array}{l}\text { Integrative } \\
\text { Gratification }\end{array}$} & INT1 & 0.707 & $<0.001$ & \multirow{4}{*}{0.794} & \multirow{4}{*}{0.397} \\
\hline & INT2 & 0.640 & $<0.001$ & & \\
\hline & INT3 & 0.728 & $<0.001$ & & \\
\hline & INT4 & 0.615 & $<0.001$ & & \\
\hline \multirow{4}{*}{$\begin{array}{l}\text { Social Interactive } \\
\text { Gratifications }\end{array}$} & SOI1 & 0.596 & $<0.001$ & \multirow{4}{*}{0.845} & \multirow{4}{*}{0.581} \\
\hline & $\mathrm{SOI} 2$ & 0.789 & $<0.001$ & & \\
\hline & SOI3 & 0.798 & $<0.001$ & & \\
\hline & SOI4 & 0.842 & $<0.001$ & & \\
\hline \multirow{3}{*}{$\begin{array}{l}\text { Attitude Towards } \\
\text { SNS }\end{array}$} & ATT1 & 0.761 & $<0.001$ & \multirow{3}{*}{0.775} & \multirow{3}{*}{0.535} \\
\hline & ATT2 & 0.727 & $<0.001$ & & \\
\hline & ATT3 & 0.706 & $<0.001$ & & \\
\hline
\end{tabular}

$\mathrm{CR}=$ Composite Reliability, $\mathrm{COG}=$ Cognitive Gratification, $\mathrm{HED}=$ Hedonic Gratification, $\mathrm{INT}=$ Integrative Gratification, SOI $=$ Social Interactive Gratification, ATT $=$ Attitude towards SNS.

Setelah dipertimbangkan, indikator COG4, HED1, INT5, dan INT6 dihapus dan tidak dimasukan ke dalam tabel 1 karena nilai loading di bawah 0.7 dan pada saat indikator dihapus nilai AVE dan CR berada di atas nilai batas.

\subsection{Discriminant Validity}

Discriminant Validity dinilai dengan melihat akar kuadrat AVE yang harus lebih tinggi dari korelasi antar variabel pada kolom yang sama dan loading indikator ke konstruk yang diukur harus lebih besar daripada ke loading ke konstruk lain [34]. Korelasi antar variabel dapat dilihat pada tabel 2. 
Tabel 2. Korelasi antar variabel

\begin{tabular}{lccccc}
\hline \multicolumn{1}{c}{ Variabel } & COG & HED & INT & SOI & ATT \\
\hline Cognitive Gratification & $\mathbf{( 0 . 7 5 9 )}$ & 0.346 & 0.305 & 0.404 & 0.377 \\
Hedonic Gratification & 0.346 & $\mathbf{( 0 . 7 6 8 )}$ & 0.390 & 0.468 & 0.489 \\
Integrative Gratification & 0.305 & 0.390 & $\mathbf{( 0 . 7 1 1 )}$ & 0.435 & 0.338 \\
$\begin{array}{l}\text { Social Interactive } \\
\text { Gratifications }\end{array}$ & 0.404 & 0.468 & 0.435 & $\mathbf{( 0 . 7 6 2 )}$ & 0.442 \\
Attitude Towards SNS & 0.377 & 0.489 & 0.338 & 0.442 & $\mathbf{( 0 . 7 3 2 )}$ \\
\hline
\end{tabular}

COG $=$ Cognitive Gratification, $\mathrm{HED}=$ Hedonic Gratification, $\mathrm{INT}=$ Integrative Gratification, $\mathrm{SOI}=$ Social Interactive Gratification, ATT = Attitude towards SNS

Diketahui bahwa variabel mempunyai cross loading rendah. Cross loading rendah artinya nilai loading antar variabel lebih rendah dari nilai loading variabel tersebut.

\subsection{Evaluasi Model Struktural}

Evaluasi model struktural dilakukan dengan melihat koefisien determinasi (R-squared), relevansi prediktif (Q-squared), dan effect size [34]. Tabel 3 menunjukkan hasil evaluasi model struktural, dengan memberikan pengamatan terhadap setiap hubungan variabel melalui pemenuhan nilai P-Value $<0.05$ [38]. Dianggap mendukung bilamana p-value $<0.05$ dan sebaliknya, jika p-value $>0.05$ maka dianggap tidak mendukung sebuah hubungan faktor.

Tabel 3. Evaluasi Model Struktural

\begin{tabular}{|c|c|c|c|c|c|c|}
\hline & & R-squared & Q-squared & $\begin{array}{c}\text { Effect } \\
\text { size }\end{array}$ & P Values & Uji hipotesis \\
\hline ATT & $\rightarrow \mathrm{COG}$ & \multirow{3}{*}{0.347} & \multirow{3}{*}{0.348} & 0.063 & $<0.001$ & Didukung \\
\hline HED & $\rightarrow$ ATT & & & 0.151 & $<0.001$ & Didukung \\
\hline INT & $\rightarrow \mathrm{ATT}$ & & & 0.028 & 0.051 & Tidak didukung \\
\hline SOI & $\rightarrow \mathrm{ATT}$ & & & 0.105 & $<0.001$ & Didukung \\
\hline SOI & $\rightarrow \mathrm{COG}$ & 0.167 & 0.168 & 0.167 & $<0.001$ & Didukung \\
\hline SOI & $\rightarrow$ HED & 0.227 & 0.228 & 0.227 & $<0.001$ & Didukung \\
\hline SOI & $\rightarrow \quad$ INT & 0.202 & 0.203 & 0.202 & $<0.001$ & Didukung \\
\hline
\end{tabular}

$\mathrm{COG}=$ Cognitive Gratification, $\mathrm{HED}=$ Hedonic Gratification, $\mathrm{INT}=$ Integrative Gratification, $\mathrm{SOI}=$ Social Interactive Gratification, ATT = Attitude towards SNS.

Instagram mampu memberikan Cognitive Gratification atau kepuasan kognitif kepada penggunanya karena pengguna bisa mendapatkan informasi lewat postingan oleh pengguna lain di timeline ataupun instastory. Terdapat berbagai macam akun di Instagram dan dari akun-akun tersebut terdapat berbagai macam informasi yang bisa didapatkan. Sebagai contoh, pengguna bisa mendapatkan informasi referensi tempat makan dengan mengikuti akun kuliner dan style pakaian masa kini dengan mengikuti akun fashion. Selain sebagai referensi, postingan di Instagram juga dapat menambah pengetahuan pengguna, contohnya pengguna dapat mengetahui berita terkini dengan mengikuti akun instagram dari acara berita TV dan akun-akun pengetahuan.

Instagram mampu memberikan Hedonic Gratification atau kepuasan hedonik kepada penggunanya karena Instagram membuat penggunanya merasa senang dan suka menjelajahi postingan di timeline maupun instastory. Postingan di Instagram juga dapat membuat pengguna merasa senang dan terhibur, 
seperti dengan melihat postingan gambar atau video lucu, postingan tentang idola, atau melihat barang di akun online shop.

Bagi pengguna Instagram di Indonesia menggunakan Instagram tidak dapat memberikan Integrative Gratification kemungkinan karena bagi pengguna Instagram di Indonesia lebih memilih menggunakan Instagram untuk mengekspresikan dan menunjukkan jati diri bukan membentuk reputasi.

Social Interactive Gratifications pengguna Instagram didapat dengan memposting postingan gambar/video lewat instastory ataupun timeline. Pada postingan tersebut pengguna lain dapat memberikan tanggapan lewat DM atau comment. DM dan kolom comment menjadi tempat untuk pengguna saling berinteraksi. Saat pengguna memposting sesuatu, pengguna merasa penasaran tanggapan seperti apa yang diberikan pengguna lain pada postingannya. Tanggapan yang diperoleh pun dapat berbagai macam seperti pujian, kritikan ataupun hal yang tidak berhubungan dengan postingannya.

Interaksi sosial yang dilakukan pengguna dapat mempengaruhi kepuasan kognitif. Hal ini bisa terjadi karena saat pengguna melakukan interaksi, mereka juga dapat menambah informasi. Pertukaran informasi melalui interaksi sosial ini terjadi saat pengguna berinteraksi satu sama lain melalui komentar pada kolom komentar dan DM.

Pengguna lebih cenderung membenamkan diri dalam interaksi dan memperoleh pengalaman yang menarik [16][22]. Dengan saling berinteraksi dengan pengguna lain, pengguna tidak hanya mendapatkan informasi selama percakapan tetapi mereka juga merasa senang selama proses ini [29]. Mereka senang karena bisa saling menceritakan cerita atau pengalaman lucu. Berinteraksi sosial dengan Instagram juga membuat pengguna tanpa sadar menghabiskan waktu dan melepas lelah.

Saat antar pengguna melakukan interaksi maka mereka juga dapat memperoleh kepuasan integratif, ini karena pengguna dapat merasa semakin dekat satu sama lain dan membentuk identitas diri ketika menemukan pengguna lain yang memiliki hobi yang sama. Contohnya, antar pengguna yang awalnya belum kenal lalu dipertermukan dengan hobi atau minat yang sama karena sama-sama mengikuti akun sepak bola, pengguna dapat menjadi akrab karena sering melakukan interaksi di aplikasi Instagram seperti saling membalas di kolom komentar atau berkirim pesan via DM. Interaksi sosial tersebut juga bisa membuat pengguna lebih tahu seperti apa pengguna lain yang memiliki kesamaan di bidang minat guna membentuk jati diri mereka.

\section{Kesimpulan dan Saran}

Berdasarkan hasil penelitian yang telah disampaikan di atas, dapat ditarik kesimpulan sebagai berikut:

1. Cognitive Gratification, Hedonic Gratification, Sosial Interactive Gratification adalah kepuasan yang didapat dalam penggunaan aplikasi Instagram di Indonesia.

2. Sosial Interactive Gratification dapat meningkatkan Cognitive Gratification, Hedonic Gratification, dan Integrative Gratification dalam penggunaan Instagram di Indonesia.

Berdasarkan hasil penelitian, maka saran-saran yang dapat diberikan untuk peneliti selanjutnya adalah sebagai berikut:

1. Bagi para social media officer khususnya penggiat Instagram di Indonesia, sangat disarankan mengoptimalkan faktor cognitive, hedonic, dan sosial interactive yang terdapat pada Instagram guna memberikan dampak yang baik bagi aktualisasi akun di Instagram.

2. Untuk penelitian selanjutnya, penambahan variabel seperti Social Influence dan Media Appeal digunakan sebagai variabel baru dalam mengekplorasi niat penggunaan sosial media.

3. Model konseptual pada penelitian ini tidak memberikan kebenaran mutlak, maka disarankan untuk melakukan penelitian kembali dengan model serupa pada studi kasus yang berbeda.

\section{Referensi}

[1] M. Mulawarman and A. D. Nurfitri, "Perilaku Pengguna Media Sosial beserta Implikasinya 
Ditinjau dari Perspektif Psikologi Sosial Terapan,” Bul. Psikol., vol. 25, no. 1, Jun. 2017.

[2] L.-Y. Huang, Y.-J. Hsieh, and Y.-C. J. Wu, "Gratifications and social network service usage: The mediating role of online experience," Inf. Manag., vol. 51, no. 6, pp. 774-782, Sep. 2014.

[3] T. Doleck, P. Bazelais, and D. J. Lemay, "Need for self-expression on instagram: A technology acceptance perspective," in 2017 3rd International Conference on Computational Intelligence \& Communication Technology (CICT), 2017, pp. 1-3.

[4] J. Apodaca, "True-self and The Uses and Gratifications of Instagram Among College-aged Females," University of Nevada, Las Vegas, 2017.

[5] Lindsey T. Bryden, "Online Dating Applications and The Uses and Gratifications Theory.," Eastern Washington University, 2017.

[6] Narudin, Pengantar Komunikasi Massa. Jakarta: PT. Raja Grafindo Persada, 2011.

[7] R. West and Lynn., Pengantar Teori Komunikasi, Analisis dan Aplikasi. Jakarta: Salemba Humanika., 2008.

[8] L. Garton, C. Haythornthwaite, and B. Wellman, "Studying Online Social Networks," J. Comput. Commun., vol. 3, no. 1, pp. 0-0, Jun. 2006.

[9] K. Soeparno, "Social Psychology: The Passion of Psychology," Bul. Psikol., vol. 19, no. 1, 2011.

[10] N. B. Ellison, J. Vitak, R. Gray, and C. Lampe, "Cultivating Social Resources on Social Network Sites: Facebook Relationship Maintenance Behaviors and Their Role in Social Capital Processes," J. Comput. Commun., vol. 19, no. 4, pp. 855-870, Jul. 2014.

[11] R. Rauniar, G. Rawski, J. Yang, and B. Johnson, "Technology acceptance model (TAM) and social media usage: an empirical study on Facebook," J. Enterp. Inf. Manag., vol. 27, no. 1, pp. 630, Feb. 2014.

[12] X. Zhu and Z. Bao, "Why people use social networking sites passively," Aslib J. Inf. Manag., vol. 70, no. 2, pp. 158-175, Mar. 2018.

[13] J. Phua, S. V. Jin, and J. (Jay) Kim, "Uses and gratifications of social networking sites for bridging and bonding social capital: A comparison of Facebook, Twitter, Instagram, and Snapchat," Comput. Human Behav., vol. 72, pp. 115-122, Jul. 2017.

[14] E. Dantoso and Mite, Teori komunikasi. Yogyakarta: Graha Ilmu, 2010.

[15] S. Nambisan and R. A. Baron, "Interactions in virtual customer environments: Implications for product support and customer relationship management," J. Interact. Mark., vol. 21, no. 2, pp. 4262, Jan. 2007.

[16] Y. W. Ha, J. Kim, C. F. Libaque-Saenz, Y. Chang, and M.-C. Park, "Use and gratifications of mobile SNSs: Facebook and KakaoTalk in Korea," Telemat. Informatics, vol. 32, no. 3, pp. 425438, Aug. 2015.

[17] A. P. J. I. Indonesia, “APJII,” 2018. .

[18] N. M. Punyanunt-Carter, J. J. De La Cruz, and J. S. Wrench, "Investigating the relationships among college students' satisfaction, addiction, needs, communication apprehension, motives, and uses \&amp; gratifications with Snapchat," Comput. Human Behav., vol. 75, pp. 870-875, Oct. 2017.

[19] J. J. Al-Menayes, "Motivations for Using Social Media: An Exploratory Factor Analysis," Int. J. Psychol. Stud., vol. 7, no. 1, Feb. 2015.

[20] A. Hicks, S. Comp, J. Horovitz, M. Hovarter, M. Miki, and J. L. Bevan, "Why people use Yelp.com: An exploration of uses and gratifications," Comput. Human Behav., vol. 28, no. 6, pp. 2274-2279, Nov. 2012.

[21] A. E. Krause, A. C. North, and B. Heritage, "The uses and gratifications of using Facebook music listening applications," Comput. Human Behav., vol. 39, pp. 71-77, Oct. 2014.

[22] L. Gao and X. Bai, "An empirical study on continuance intention of mobile social networking services,” Asia Pacific J. Mark. Logist., vol. 26, no. 2, pp. 168-189, Apr. 2014. 
[23] S. Alhabash, Y. Chiang, and K. Huang, "MAM \&amp; U\&amp;G in Taiwan: Differences in the uses and gratifications of Facebook as a function of motivational reactivity," Comput. Human Behav., vol. 35, pp. 423-430, Jun. 2014.

[24] W. Chaouali, "Once a user, always a user: Enablers and inhibitors of continuance intention of mobile social networking sites," Telemat. Informatics, vol. 33, no. 4, pp. 1022-1033, Nov. 2016.

[25] E. B. Weiser, "The Functions of Internet Use and Their Social and Psychological Consequences," CyberPsychology Behav., 2002.

[26] W. Pahnke, "Drugs and mysticism," Int. J. Parapsychol., vol. 8, no. 2, 1966.

[27] J. Brown, A. J. Broderick, and N. Lee, "Word of mouth communication within online communities: Conceptualizing the online social network," J. Interact. Mark., 2007.

[28] H.-S. Chiang, "Continuous usage of social networking sites," Online Inf. Rev., vol. 37, no. 6, pp. 851-871, Nov. 2013.

[29] L. Humphreys, "Mobile Social Networks and Social Practice: A Case Study of Dodgeball," J. Comput. Commun., vol. 13, no. 1, pp. 341-360, Oct. 2007.

[30] I. Ajzen, "Nature and Operation of Attitudes," Annu. Rev. Psychol., vol. 52, no. 1, pp. 27-58, Feb. 2001.

[31] A. V. Hausman and J. S. Siekpe, "The effect of web interface features on consumer online purchase intentions," J. Bus. Res., vol. 62, no. 1, pp. 5-13, Jan. 2009.

[32] J. F. Hair, C. M. Ringle, and M. Sarstedt, "PLS-SEM: Indeed a Silver Bullet," J. Mark. Theory Pract., vol. 19, no. 2, pp. 139-152, Apr. 2011.

[33] Latan and Imam, Partial least squares konsep, metode dan aplikasi menggunakan metode WarpPLS 5.0. Semarang: Badan Penerbit Universitas Diponegoro, 2012.

[34] Sholihin and Dwi, Bukunya Analisis SEM- PLS dengan WARPLS 3.0. Yogyakarta: C.V ANDI OFFSET, 2013.

[35] Sudarmanto, In Statistic Terapan Berbasis Komputer dengan IBM SPSS Statistics 19. Jakarta: Mitra Wcana Media, 2013.

[36] Abdillah, Willy, and Jogiyanto, Partial Least Square (PLS): AlternatifStructural Equation Modeling (SEM) dalam Penelitian Bisnis. Yogyakarta: ANDI, 2015.

[37] J. F. Hair, C. M. Ringle, and M. Sarstedt, "Partial Least Squares Structural Equation Modeling: Rigorous Applications, Better Results and Higher Acceptance," Long Range Plann., 2013.

[38] N. C. Wibowo, T. L. M. Suryanto, A. Faroqi, and R. Hadiwiyanti, "Understanding the Dominant Factors towards the Intention to Use Youtube continuously in Indonesia," in Proceedings of the International Conference on Science and Technology (ICST 2018), 2018. 